\title{
Fetomaternal outcome in pregnancy with oligohydramnios
}

\author{
Jay Y. Modi*, Rina V. Patel, Parul T. Shah, Amish G. Agrawal
}

Department of Obstetrics and Gynaecology, VS General Hospital, Ellisbridge, Ahmedabad, Gujarat, India

Received: 15 September 2016

Revised: 18 September 2016

Accepted: 08 October 2016

\section{*Correspondence:}

Dr. Jay Y. Modi,

E-mail: modi.jay2@gmail.com

Copyright: (C) the author(s), publisher and licensee Medip Academy. This is an open-access article distributed under the terms of the Creative Commons Attribution Non-Commercial License, which permits unrestricted non-commercial use, distribution, and reproduction in any medium, provided the original work is properly cited.

\begin{abstract}
Background: Oligohydramnios has been correlated with increased risk of FGR, meconium aspiration, birth asphyxia, low APGAR scores and congenital anomalies. Early detection of oligohydramnios and its management may help in reduction of perinatal morbidity and mortality. The aim and objectives of the study was to study the effect of oligohydramnios on fetal outcome in form of FGR, fetal distress, altered APGAR scores, NICU admission and early neonatal morbidity and mortality and to study maternal morbidity in the form of operative delivery and induced labour.

Methods: 100 patients in third trimester of pregnancy with oligohydramnios confirmed by ultrasound measurement of AFI were selected randomly after satisfying inclusion and exclusion criteria.

Results: Incidence of oligohydramnios and operative intervention for the same was seen more in primipara (52\%). Most common causes of oligohydramnios were idiopathic (52\%) followed by PIH (25\%). Operative morbidity was highest in PIH (60\%). Most common indication of caesarean section was fetal distress due to cord compression or FGR. 7\% patients had fetoplacental insufficiency on Doppler study.

Conclusions: Oligohydramnios demands intensive fetal surveillance and proper antepartum and intrapartum care. Due to high rates of intrapartum complications, perinatal morbidity and mortality, rates of caesarean section are rising, but decision between vaginal delivery and caesarean section should be well balanced so that unnecessary operative morbidity is prevented without jeopardizing the fetal well-being.
\end{abstract}

Keywords: Oligohydramnios, Pregnancy

\section{INTRODUCTION}

Amniotic fluid is vital to the well-being of the fetus. It cushions the fetus from injury, helps prevent compression of the umbilical cord, and allows room for it to move and grow. In addition, its bacteriostatic action helps prevent infection of the intra-amniotic environment. The quantity of amniotic fluid at any time during gestation is the product of water exchange between the mother, fetus, and placenta, and is maintained within a relatively narrow range. Disorders of this regulatory process can lead to either polyhydramnios or oligohydramnios, in which too much or too little fluid exists, respectively. These disorders may result from abnormal fetal or maternal conditions and, conversely, may be responsible for alterations of fetal well-being as well. With the advent of real-time ultrasonography, assessment of amniotic fluid has been possible, resulting in earlier recognition of abnormal conditions and possible intervention.

Proper clinical assessment of amniotic fluid volume was difficult in the past. Better identification of at-risk fetus can be done now by using the Amniotic Fluid Index (AFI) method described by Phelan et al, where the four quadrant technique is employed during trans abdominal ultrasound. ${ }^{1}$ 
Decrease in amniotic fluid volume or oligohydramnios is defined as "a condition where the liquor amnii is deficient in amount to the extent of less than $200 \mathrm{ml}$ at term." Sonographically, it is defined when the single largest vertical pocket of liquor is less than $<2 \mathrm{~cm}$ (below $5^{\text {th }}$ percentile). Absent of any measurable pocket of amniotic fluid is defined as anhydramnios. AFI between $5 \mathrm{~cm}$ and $8 \mathrm{~cm}$ is termed as borderline AFI or borderline oligohydramnios described by Hiralal Konar, D C Dutta. ${ }^{2}$

Oligohydramnios has been correlated with increased risk of fetal growth retardation (FGR), meconium aspiration syndrome (MAS), severe birth asphyxia, low APGAR scores and congenital anomalies. Oligohydramnios is also associated with maternal morbidity in form of increased rates of induction and/or operative interference carried out to improve the perinatal outcome described by Jeng Lee Wang Yang. ${ }^{3}$

\section{Aim and objectives}

1. To study effects of oligohydramnios on fetal outcome in the form of:

- FGR

- Fetal distress during labour and APGAR scoring immediately post-partum

- $\quad$ NICU admission leading to neonatal morbidity and/or mortality.

2. To study maternal morbidity in the form of operative delivery and induced labour.

\section{METHODS}

Present study was done over a period from July 2015 to June 2016.

100 patients in the third trimester of pregnancy with oligohydramnios selected randomly after satisfying inclusion and exclusion criteria.

\section{Inclusion criteria}

Antenatal patients in their third trimester with intact membranes.

\section{Exclusion criteria}

Antenatal cases having premature rupture of membranes; multiple pregnancy; vomiting and dehydration in $1^{\text {st }}$ trimester of pregnancy.

\section{Method}

- A detailed history taken and thorough examination is done.

- All required investigations done.

- Oligohydramnios confirmed by measuring AFI.
- Fetal surveillance was done by USG, Modified Biophysical profile (NST and AFI) and Doppler.

- Decision of delivery by either induction or elective or emergency LSCS was done as per required. Cases were than studied for maternal and perinatal outcome.

\section{RESULTS}

100 cases of oligohydramnios from the month of July 2015 to June 2016 admitted in our hospital were studied.

Table 1: Age, parity and maternal outcome of labour.

\begin{tabular}{|lllll|}
\hline Age & Normal & $\begin{array}{l}\text { Assisted } \\
\text { (Forceps) }\end{array}$ & Caesarean & $\begin{array}{l}\text { Total } \\
(\mathbf{n}=\mathbf{1 0 0})\end{array}$ \\
\hline$<20$ & $3(75 \%)$ & & $1((25 \%)$ & 4 \\
\hline $20-25$ & $\begin{array}{l}39 \\
(58.2 \%)\end{array}$ & $1(1.5 \%)$ & $27(40.3 \%)$ & 67 \\
\hline $26-30$ & $\begin{array}{l}10 \\
(43.48 \%)\end{array}$ & $\begin{array}{l}13 \\
(56.52 \%)\end{array}$ & 23 \\
\hline$>30$ & $5(83.3 \%)$ & & $1(16.66 \%)$ & 6 \\
\hline Parity & & & & \\
\hline Primipara & $\begin{array}{l}22 \\
(42.30 \%)\end{array}$ & $1(1.92 \%)$ & $29(55.78 \%)$ & 52 \\
\hline Multipara & $\begin{array}{l}35 \\
(72.91 \%)\end{array}$ & $\begin{array}{l}13 \\
(27.09 \%)\end{array}$ & 48 \\
\hline
\end{tabular}

Oligohydramnios was associated with following conditions which may operate as etiological factors.

Table 2: Associated conditions (etiology) and maternal outcome of labour.

\begin{tabular}{|lllll|}
\hline $\begin{array}{l}\text { Associated } \\
\text { conditions }\end{array}$ & Normal & $\begin{array}{l}\text { Assisted } \\
\text { (Forceps) }\end{array}$ & Caesarean & $\begin{array}{l}\text { Total } \\
\text { (N=100) }\end{array}$ \\
\hline PIH & $10(40 \%)$ & - & $15(60 \%)$ & 25 \\
\hline Postdatism & $13(65 \%)$ & - & $7(53 \%)$ & 20 \\
\hline Fever & $3(100 \%)$ & - & - & 3 \\
\hline Idiopathic & $\begin{array}{l}31 \\
(59.61 \%)\end{array}$ & $1(1.92 \%)$ & $\begin{array}{l}20 \\
(38.47 \%)\end{array}$ & 52 \\
\hline
\end{tabular}

All patients undergone umbilical Doppler study on the basis of PI (pulsatility index) normal value in $3^{\text {rd }}$ trimester: 1.18 (SD +/- 0.25). There are 7\% found with fetoplacental insufficiency described by Caroll BC and manning et al. 6,7

Table 3: Doppler.

\begin{tabular}{|lllll|}
\hline \multirow{2}{*}{ Doppler } & \multicolumn{2}{l}{ Vaginal delivery } & Caesarean & Total \\
& Normal & $\begin{array}{l}\text { Assisted } \\
\text { (Forceps) }\end{array}$ & $\begin{array}{l}\text { Calivery } \\
\text { del00) }\end{array}$ & (N=10 \\
\hline Normal & $\begin{array}{l}57 \\
(61.29 \%)\end{array}$ & $1(1.07 \%)$ & $\begin{array}{l}36 \\
(38.71 \%)\end{array}$ & 93 \\
\hline Abnormal & $\begin{array}{l}1 \\
(14.29 \%)\end{array}$ & - & $6(85.71 \%)$ & 7 \\
\hline
\end{tabular}


Table 4: Both biophysical profile (NST+AFI) and Doppler.

\begin{tabular}{|lllll|}
\hline Delivery & Both $\mathbf{N}$ & $\begin{array}{l}\text { Both } \\
\text { A b N }\end{array}$ & $\begin{array}{l}\text { One Ab } \\
\text { N }\end{array}$ & $\begin{array}{l}\text { Total } \\
(\mathbf{N}=100)\end{array}$ \\
\hline Vaginal & 49 & 0 & 9 & 58 \\
\hline Caesarean & 13 & 1 & 28 & 42 \\
\hline
\end{tabular}

\section{Induction of labour}

Total 25 patients had induction of labour. Out of them cerviprime was used in 18 and misoprost in 4 and oxytocin in 3 patients.

\section{Intrapartum complication}

Out of 100, 31 patients had intrapartum complication in form of MSL with non-reassuring heart rate pattern.

\section{Indications of caesarean section}

Out of 100 patients LSCS was done in 42 patients for following indications.

Table 5: Indications of caesarean section.

\begin{tabular}{|l|l|l|}
\hline Indications & Casey et al $^{4}$ & Present study \\
\hline Fetal Distress & $32.6 \%$ & $21 \%$ \\
\hline Oligohydramnios & - & $9 \%$ \\
\hline FPI, IUGR & - & $8 \%$ \\
\hline Breech & - & $2 \%$ \\
\hline Others & - & $2 \%$ \\
\hline
\end{tabular}

Table 6: Oligohydramnios and perinatal outcome.

\begin{tabular}{|c|c|c|c|}
\hline $\begin{array}{l}\text { Factors } \\
\text { associated with } \\
\text { perinatal } \\
\text { outcome }\end{array}$ & $\begin{array}{l}\text { Present } \\
\text { study }\end{array}$ & $\begin{array}{l}\text { Casey } \\
\mathrm{BM}^{4}\end{array}$ & $\begin{array}{l}\text { Manning et } \\
\text { al study }^{8}\end{array}$ \\
\hline $\begin{array}{l}\text { Growth } \\
\text { retardation } \\
\text { AGA } \\
\text { SGA }\end{array}$ & $\begin{array}{l}82 \% \\
18 \%\end{array}$ & $\begin{array}{l}75.5 \% \\
24 \%\end{array}$ & $\begin{array}{l}64 \% \\
36 \%\end{array}$ \\
\hline $\begin{array}{l}\text { APGAR Score } \\
(<7 \text { in } 1-5 \mathrm{~min})\end{array}$ & $15 \%$ & - & $15 \%$ \\
\hline $\begin{array}{l}\text { NICU } \\
\text { admission }\end{array}$ & $22 \%$ & - & $43 \%$ \\
\hline $\begin{array}{l}\text { Congenital } \\
\text { anomaly }\end{array}$ & $1 \%$ & $10 \%$ & $13 \%$ \\
\hline $\begin{array}{l}\text { abN biophysical } \\
\text { profile } \\
\text { (abN NST+AFI) }\end{array}$ & $32 \%$ & $48 \%$ & \\
\hline Perinatal death & $4 \%$ & $6.3 \%$ & - \\
\hline
\end{tabular}

\section{DISCUSSION}

Mean maternal age - Casey et al 23.9 years - present study - 23.66 years. ${ }^{4}$

Thus, incidence of oligohydramnios was more in primipara $(52 \%)$ in our study. And operative morbidity was also more in primipara $(57.7 \%)$. Most common cause of oligohydramnios is idiopathic (52\%), and second commonest cause is PIH (25\%). Operative morbidity is highest in PIH (60\%). Idiopathic is most common cause of oligohydramnios in Casey BM (60.5\%) and Magnan EF $(28.5 \%)$ like our study $(52 \%) .{ }^{4,5}$ Casey BM show highest operative delivery $71 \%$ which is found in our study $(85.71 \%){ }^{4}$ So operative morbidity was significantly higher in patients with altered Doppler. As our patients had oligohydramnios, a non-reactive NST + AFI <5 indicated fetal geopardy as per revised Biophysical profile scoring by manning et al and this fetal geopardy is reflected as increased operative interference in our study. ${ }^{8}$

38 patients had one of the investigations abnormal and rates of caesarean delivery were increased in this group. Casey BM shows 68\% vaginal deliveries in induced patients of oligohydramnios and $32 \%$ by LSCS which is comparable to our study as vaginal deliveries $64 \%$ and LSCS $34 \%$ respectively. ${ }^{4}$

\section{Maternal morbidity outcome}

In Present study, $25 \%$ of the patients had undergone induction of labour by cerviprime, misoprost or oxytocin. All of them had antepartum fetal surveillance in form of biophysical profile and Doppler described by magnan meta-analysis. ${ }^{9}$ No induction was performed in abnormal Doppler. So 16 patients out of 25 total induced patients were delivered vaginally, whereas 9 patients delivered by LSCS. In our study, we had intrapartum complication in form of MSL with non-reassuring heart rate pattern (26\%) and fetal distress alone (5\%). Which is comparable to study done by Casey et al - $(32 \%)$ and manning et al (38\%) most common reason to perform caesarean was fetal distress which was either due to cord compression or IUGR. ${ }^{4,8}$ Results are comparable with Casey et al study, which show significant higher proportion of CS due to fetal distress. ${ }^{8}$ There is high rate of operative delivery (instrumental + LSCS) in all the studies which are comparable to present study. Thus, oligohydramnios is associated with increased operative delivery and therefore, increased maternal morbidity.

The Fetal outcome in pregnancy with isolated reduced AFV in third trimester described by Robert and Walinshaw. ${ }^{10}$ Causes of 4 perinatal death: 1 due to Septicemia , 1 due to prematurity and 2 due to meconium aspiration syndrome in present study.

\section{Neonatal morbidity outcome}

8 mothers had abnormal biophysical profile (NST + AFI) out of which 2 delivered vaginally and 6 by caesarean and all babies survived. Out of them 3 delivered by LSCS and 2 delivered vaginally were admitted in NICU but on discharge all babies were well. No neonatal mortality noted in this study. An abnormal biophysical profile (NST+AFI), induction and vaginal delivery can be 
contemplated hoping successful perinatal outcome described by Kennedy $\mathrm{K}$ et al and Williams and simultaneously maternal operative morbidity can be reduced. ${ }^{11,12}$

\section{CONCLUSION}

Oligohydramnios is frequent occurrence and demands intensive fetal surveillance and proper antepartum and intrapartum care. Oligohydramnios is frequent findings in pregnancies involving IUGR, PIH and pregnancies beyond 40 weeks of gestation. AFI is a predictor of fetal tolerance in labour and its decrease is associated with increased risk of abnormal heart rate and meconium stained fluid. Due to intrapartum complication and high rate of perinatal morbidity and mortality, rates of caesarean section are rising, but decision between vaginal delivery and caesarean should be well balanced so that unnecessary maternal morbidity prevented and other side timely intervention can reduce perinatal morbidity and mortality.

\section{Funding: No funding sources}

Conflict of interest: None declared

Ethical approval: The study was approved by the Institutional Ethics Committee

\section{REFERENCES}

1. Phelan JP, Smith CV, Small M. Amniotic fluid volume assessment with the four quadrant technique: J Reprod Med. 1987;32:540-2.

2. Konar H. D C Dutta's Textbook of obstetrics. 2015;8:250-251.
3. Jeng CJ, Lee JF, Wang KG. Yang YC, Lan CC. Decreased AFI in term pregnancy. Clinical significance. J. Repord Med. 1992;37(9):789-92.

4. Casey BM. Pregnancy outcome after antepartum diagnosis of oligohydramnios at or beyond 34 weeks gestation. Am J Obstet Gynaecol. 2000;182:909-12.

5. Magann EF, Mortan ML, Nolan TE Martin JN, Whitworth NS, Morrison JC. Comparative efficacy of sonographic measurements for the detection of aberrations in the amniotic fluid volume on pregnancy outcome. Obstet Gynecol. 1994;83:95962.

6. Carroll BC, Bruner JP. Umbilical artery Doppler velocimetry in pregnancies complicated by oligohydramnios. J Repord. Med. 2000;45:562-6.

7. Hill LM, Platti LD. Quantitative amniotic fluid volume determination by ultrasound. Am J Obstet Gynecol. 1981;139:254-8.

8. Harman CR, Morrison I, Menticoglou SM. Lange IR, Jhonson JM. Fetal Assessment based on fetal biophysical profile scoring. Am J Obstet Gynecol. 1990;162(3):703-9.

9. Chauhan SP, Sanderson M. Hendrix NW, Magnan EF, Devoe LD. Perinatal outcome and AFI in the antepartum and intrapartum period; a meta-analysis. Am J Obstet Gynecol. 1999;181:1473-8.

10. Roberts D, Mwosu EC, Walkinshaw SA. The Fetal outcome in pregnancy with isolated reduced AFV in third trimester J. Perinatal med. 2001;46:589-92.

11. Dizon-Townston N, Kennedy K. AFI and perinatal morbidity. Am J Perinatal. 1996;13(4):231-4.

12. Williams: Textbook of obstetric 23rd Edition, 49598.

Cite this article as: Modi JY, Patel RV, Shah PT, Agrawal AG. Fetomaternal outcome in pregnancy with oligohydramnios. Int J Reprod Contracept Obstet Gynecol 2016;5:4037-40. 